\title{
An Estimation of the Impact of Financial Intermediation on the Economic Growth of Ghana; With Emphasis on the Private Sector
}

\author{
Asiamah Yeboah
}

\begin{abstract}
It is an undeniable and acceptable fact that all economic agents namely; individuals, corporations and governments require money to meet their specific needs which may differ from one economic agent to another. The monetary activities of these economic agents which have to be financed by someone else exert an overall effect on the entire economy. The challenge here, therefore, is about the availability of banks' credit and its allocation to the various economic agents as well as the economic results they deliver to Ghana's economy. Thus, the basic issue which the study sought to dwell on is 'how commercial banks' credit allocated to the private sector impacts on the growth of the entire economy of Ghana'. The study conducted is exploratory in nature and the approach was purely quantitative making use of secondary data relating to financial intermediation and economic growth spanning from 1993 to 2018. Purposive sampling technique was used in selecting data and its source. To estimate the parameters in the econometric model stated in the study using times series data, AutoRegressive Distributive Lag (ARDL) bounds testing approach to co-integration developed by Pesaran et al. was employed. Overall, the empirical evidence obtained indicates that there is a negative long-run relationship between domestic banks credit to the private sector and Ghana's economic growth, though statistically insignificant at 5\% significance level. In the shortrun however, the negative relationship between the two variables is statistically significant at the same significance level.
\end{abstract}

Index Terms - financial intermediation, economic growth, private sector.

\section{INTRODUCTION}

Finance is required by all economic agents such as individuals, corporations and governments to meet specific needs which may differ from one economic agent to another at any point in time. The monetary activities of economic agents exert an overall effect on the entire economy. To enhance efficient provision of finance in any economic environment; there must be institutions with the requisite capacity to efficiently deliver financial services. These institutions may be banking or non-banking, depository or non-depository institutions which are collectively called Financial Institutions. Most financial institutions operate in a financial market through a process known as financial intermediation. Financial markets may be classified as money or capital market, primary or secondary and organized or over-the-counter market. Financial intermediation is a mechanism by which funds are channeled from surplus spending unit (lender) to the productive deficit spending unit (borrower) through financial intermediaries such as the commercial banks. By this intermediation mechanism, banks idle deposits are given out as credits for productive investments.

The role of credit in any economy cannot be overemphasized as credit facilities enable economic agents to meet their expenditure needs. For instance, business entities obtain credit to buy machinery and equipment, farmers take loans to buy seeds, fertilizers, erect various kinds of farm structures and government and publicly owned institutions obtain credits to meet various kinds of recurrent and capital expenditures [1].

Agbada [2] rightly observes that availability of bank credit allows corporate institutions to increase production, output and efficiency which in turn enhance the profitability of banks through interest and debt repayment. According to Nwanyanwu [3], through financial intermediation bank credit gets to individuals and investors with brilliant ideas on how to create additional wealth in the economy but lacks the financial backing to execute such ideas.

It is noted that in developing economies such as Ghana, the banking sector has stood out in the financial sector as one of prime importance since the banking sector is virtually the only financial means of attracting savings on a large scale [4]. This assertion is buttressed by King and Levine [5], [6] who indicate that banks have an overwhelmingly dominant position in the financial system of developing economies and are extremely important engines of economic growth. They add that since financial markets are usually under-developed in such economies, banks in developing economies are typically the most important source of finance for majority of firms. They also assert that, as well as providing a generally accepted means of payment, banks in developing countries are usually the main depository institutions for the economy's savings. The importance of financial systems and intermediation in generating growth within an economy has been widely discussed in the literature and it dates back to early economists such as Schumpeter who in 1911 identified banks' role in facilitating technological innovation through their intermediary role as crucial. Schumpeter [7] posited that efficient allocation of savings through identification and funding of entrepreneurs with the best chances of successfully implementing innovative products and production processes are tools to achieve economic growth. This hypothesis is often referred to as "supply-leading" hypothesis. Several scholars thereafter [5], [6], [8]-[11] have 
supported this postulate about the supply of banks credit enhancing productive capacity and thereby resulting in growth of an economy.

There is yet another related but a reverse hypothesis known as "demand-following" hypothesis which explains that economic growth rather has a causal effect on financial intermediation. Proponents of "demand-following" hypothesis explain that the expansion of the economy rather pushes the real sector to demand for banks credit (finance) so as to cope with the increase in productivity [11]-[13]. Thus, economic growth pushes the financial institutions to provide credit according to this hypothesis.

A financial system consists of the various arrangements used to create and exchange claims with the overall effect of these transactions trickling down to the economy, be it positive or negative. In every modern economy there are three basic economic agents as mentioned earlier, these are households, businesses and government.

Households receive income (wages and salaries) and make several expenditures on consumer goods. Business firms get their revenue from the sale of goods and services to households, other business firms and government. Businesses in turn incur expenditures on the use of factor resources in the form of payment of wages, rents, raw materials etc.

Government also obtains its revenue from taxes collected and other charges such as fees and fines. It then makes expenditures on the provision of public goods, programs and other social services. These services include the provision of health, education, roads, security services, and other social welfare support systems. An economic agent may have a balanced budget, a surplus budget, or a deficit budget depending on revenue and expenditure forecasts.

The basic role of the financial system therefore is to channel funds from the surplus unit (i.e. those with current incomes exceeding their current expenditure) to the deficit unit (i.e. those who desire to spend more than their current income) through savings accumulation and lending. This task of funds transfer from the surplus unit to the deficit unit is usually accomplished through direct financing or an intermediated financing approach referred to as financial intermediation.

With the direct financing, deficit units issue financial securities such as bonds and sell them directly for money to surplus units. These securities are usually sold in a credit market such as the money or capital markets directly. The disadvantage, however, is that deficit units must find surplus units who want the precise securities they intend to sell.

With financial intermediation however, net savers save their surplus funds with financial intermediaries which are aggregated and given to the deficit unit as credit. By this mechanism economic progress can be achieved through efficient redistribution of idle resources of the surplus units to meet the wealth creating needs of the deficit's units. This is the focal point of the mechanism of financial intermediation.

In most cases business firms and governments are the deficit spending units due to their large project investments requirements. Households on the other hand are usually the surplus spending unit and are described as net savers. Thus, aggregated savings are being competed for by the private sector and the public sector through lending from the commercial banks. The private sector firms are more likely to create additional wealth with banks credit through investor ingenuity as the sector is often touted as the engine of growth but are deemed riskier to lend to by the banks compared to lending to government and other public institutions with government guarantees. The credit allocation trend in Ghana therefore seems to lack the efficiency highlighted by [14][16].

Economic growth also has widely been defined in literature as a positive change in the national income or the level of production of goods and services by a country over a certain period of time. This often has been measured in terms of the level of productivity within the economy. Other common measures of economic growth include total factor productivity; factors of production such as technological change, human capital termed as the Schumpeterian approach and other measures of growth such as real per capita GDP [17].

However, studies have revealed that quite a number of businesses in Africa with emphasis on small and medium scale firms are credit-constrained regardless of the meaningful contribution of such private firms to economic growth [18]-[20] and the case of Ghana is no exception. This in turn constrains the productive capacity of the private sector of the economy. Consequently, the economy stagnates or declines due to lack of adequate funding for the private sector projects in the form of credit from the banking sector.

Though the private sector is often touted as the engine of growth, the sector is deemed riskier to lend to by the banks compared to lending to government and other public institutions with government guarantees. Thus, there is considerable level of reluctance and general apathy on the part of banks in developing economies like Ghana to lend to the private sector due to the perceived element of risk attached to private businesses [21]. Banks rather prefer to lend to government through the purchase of short and longterm government securities which are considered risk-free. This observation is in line with Kwakye [22] who finds that the cost of banks credit is persistently high in Ghana and he attributes this to competitive borrowing by government. Also, this assertion by Kwakye [22] is further buttressed by Abubakar and Gani [23] who also indicate that credit to the private sector is hindered by the problems of government borrowing and high interest rate which crowd out investment and growth of Nigerian economy.

However, a review of available literature on financial intermediation and economic growth reveals that most available researches look at the public sector as against the private sector in economic development, even though the latter is seen as the engine of growth. Again, most of the researches available focus on the developed countries with few ones focusing on the constraints facing SMEs in getting credit in Africa without looking at the efficiency in the allocation of this credit even though [14]-[16] highlight the importance of efficiency in the allocation of credit to economic agents than a general banking intermediation. They add that credit to the public sector is weak in generating the needed growth within the economy because such credit to the public sector are prone to waste and politically motivated programmes which may not deliver the expected result. This 
has therefore created a gap in literature which needed to be filled. The problem here, therefore, is about availability of banks' credit and its allocation to various economic agents as well as the economic results they deliver to Ghana's economy at large with a particular emphasis on credit to the private sector. Thus, the basic issue which the study sought to dwell on is "how commercial banks credit allocated to the private sector impacts the entire economy of Ghana" so as to inform policy strategy and implementation. That is, this study was conducted to assess the impact domestic credit to the private sector exerts on the growth of the economy of Ghana.

\section{RESEARCH HYPOTHESIS}

In line with the above stated objectives, this study sought to test the following hypotheses:

- Null: There is insignificant long-run relationship between commercial banks credit provision to the private sector and Ghana's economic growth.

Alternate: There is a significant long-run relationship between commercial banks credit provision to the private sector and Ghana's economic growth.

- Null: There is insignificant short-run relationship between commercial banks credit to the private sector and the growth of Ghana's economy.

Alternate: There is a significant short-run relationship between commercial banks credit to the private sector and the growth of Ghana's economy.

- Null: There is insignificant long-run relationship between banks interest rate and the growth of Ghana's economy.

Alternate: There is a significant long-run relationship between banks interest rate and the growth of Ghana's economy.

- Null: There is significant long-run relationship between total natural resource rents and the growth of Ghana's economy.

Alternate: There is insignificant long-run relationship between total natural resource rents and the growth of Ghana's economy.

\section{LITERATURE REVIEW}

\section{A. Introduction}

This chapter seeks to do a thorough review of previous studies and discussions done on Financial Intermediation and its Effect on Economic growth. The review will basically dwell on empirical studies and their findings as well as the theories behind the variables being studied.

\section{B. Conceptual Review Of Financial Intermediation}

The focal point of financial intermediation is the aggregation of idle funds from surplus units by financial intermediaries and the provision of credit to productive deficit units in the economy.

According to Nwanyanwu [3] credit is the money from the lender to the borrower. Spencer [24] also indicates that credit implies a promise by one party to pay another for money borrowed or goods and services received. In the process of financial intermediation banks and other financial intermediaries therefore simultaneously become debtors to the depositors of funds (surplus units) and creditors to the borrowers of funds (deficit units). Credit enables idle funds in the form of savings to be channeled into productive investment thereby enhancing economic growth. Financial intermediation thus plays a crucial role in economic development.

Also, the concept of economic growth is viewed as an increase in the net national product in a given period of time. Dewett [25] explains economic growth as a quantitative change in economic variables, normally persisting over successive periods. Todaro and Smith [26] sees economic growth as a steady process by which the productive capacity of the economy is increased overtime to bring about rising levels of national output and income. Economic growth has been measured in literature using such economic variables as Gross Domestic Product (GDP), Human Development Index (HDI) which measures national growth in terms of life expectancy, educational attainment, literacy and adjusted real per capita income.

The main characteristics of economic growth are high rate of growth of per capita income or output, high rate of productivity, high rate of structural transformation, international flows of labour, goods and capital [27].

\section{Theoretical Review Of Financial Intermediation}

Current financial intermediation theory builds on the assumption that intermediaries play a role only to reduce transaction costs and information asymmetry, but it does not provide a satisfactory answer to the question of why real-life financial institutions exist, what keeps them alive and what contribution they make to national economic welfare [28].

The present theory is based on the framework of the agency theory and the theory of information asymmetry which traces its origin to the classical idea of the perfect market introduced by Marshall and Walras. This idea of perfect market has been the leading principle underpinning the present theory of financial intermediation and the focal point of other theories such as the theory of competition, the neoclassical growth theory and the portfolio theory.

According to the theory of perfect market, financial intermediaries are useful only because financial markets are not perfect. Thus, banks and other financial intermediaries exist only by the grace of market imperfections, that as long as there are market imperfections, there are intermediaries. As soon as markets are perfect and reaches the ArrowDebreu world, intermediaries are no longer useful and are rendered redundant; they become functionless since savers and investors have perfect information needed to find each other directly, immediately and without any impediments, so without costs, and to deal at optimal prices [28]. Thus, as developments in information technology, deregulation, deepening of financial markets, etc. tend to reduce transaction costs and informational asymmetry and tilt the market towards the Arrow-Debreu world, the existence of financial intermediaries and their intermediation functions per the theory of perfect market must be almost extinct and wiped off in this age of globalization.

However, in real-life situation financial intermediaries are becoming more and more relevant in modern economies even as transaction cost and information asymmetries keep dwindling due to modernisation through information 
technology and deregulation. According to Scholtens and van Wensveen [28], there are empirical observations which point to the fact that there is an increasing role for financial intermediaries in economies that experience vastly decreasing information and transaction costs. This trend tends to conflict with perfect market theory which is the reference point of financial intermediation. This is a paradox! From this paradox, Scholtens and van Wensveen [28] conclude that current financial intermediation theory fails to provide a satisfactory understanding of the existence of financial intermediaries. In other words, information asymmetry emanating from market imperfections cannot be the driving force behind financial intermediation.

In the estimation of Scholtens and van Wensveen [28], the concept of value creation in the context of the value chain might actually be driving the existence and the everincreasing activities of financial intermediaries. According to them risk and risk management is inherent in value creation activities of financial intermediaries and therefore drives this phenomenon and that the absorption of risk is the central function of intermediaries such as banking and insurance. This assertion is reinforced by Allen and Santomero [29] who suggested a central role of risk in the intermediation process and proposed that risk management become the main item in the research agenda.

The risk function of the intermediaries helps to bridge the mismatch between the suppliers of funds (surplus units) and the demand for investments (deficit units) as the former are on average more risk averse than real investors.

Risk here simply refers to the deviation from expectations as the future is never predicted with certainty and they include maturity risk, counterparty risk, market risk (interest rate and stock prices fluctuations), life expectancy, income expectancy risk etc. Identifying and managing these risks is the core business of the financial industry [28]. Scholtens and van Wensveen [28] explain that financial intermediaries have the capability of soaking risk due to their sufficiently diversified portfolio of investments needed to offer the security required by savers and policyholders. Thus, financial intermediaries are not just agents who only screen and monitor on behalf of savers but are active counterparts themselves offering specific products that cannot be offered by individual investors to savers, especially cover for risk. They use their reputation and their balance sheet and offbalance sheet items, rather than their very limited own funds, to act as such counterparts. As such, they have a crucial function within the modern economy which tends to become more and more paramount even with reduced information disparity.

\section{Theoretical Review Of Economic Growth}

Several growth models have been discussed in literature. Some of these models include Two-Gap Model, Marxian Theory, Schumpeterian Theory, Harrod-Domar Theory of Growth, Neo-Classical Model of Growth and Endogenous Growth Theory, to mention a few. However, there seems to be no consensus as to which growth strategy will achieve the best results when adopted. Two of these growth models namely Neo- Classical Model of Growth and Endogenous Growth Theory are discussed by this study due to its perceived relevance to developing economies such as Ghana.
The Neo-Classical Model of Growth was advanced by economist such as Solow [30], Swan [31] and the British economist, J. E. Meade. The model stresses on capital accumulation and the related saving decision as a determinant of economic the growth. The model employs two factor-inputs as the determinants of economic output, and these are capital and labour with technology added as an exogenous variable. Thus, the production function in the Neo-Classical Model of Growth is given as $\mathrm{Y}=\mathrm{T} \mathrm{f}(\mathrm{K}, \mathrm{L}), \mathrm{Y}$ is GDP (a measure of economic output), $\mathrm{K}$ is Capital stock, $\mathrm{L}$ is Labour and $\mathrm{T}$ is Technology (an exogenous variable).

This model explains that sustained increase in capital investment or supply alone will only result in a temporal economic growth. The reason being that the ratio of capital to labour increases which implies that there is more capital available for each worker to use but the marginal product of additional units of capital declines with time and the economy eventually coils back to a long-term growth path, with real GDP growing at a constant rate as labour plus a factor (usually technology) to reflect improving productivity [1]. A "steady-state growth path" is reached when output, capital and labour are all growing at the same rate, so output per worker and capital per worker are constant. NeoClassical economists therefore believe that an economy's long-term growth rate to increased and sustained, it requires an increase in the labour supply and efficiency in the productivity of labour and capital [1]. Differences in the rate of technological change are said to explain much of the variation in economic growth between developed countries. The neo-classical model considers productivity efficiency as an exogenous variable meaning that productivity is assumed to be independent of capital investment [36]. According to Nnanna et al. [37], Solow's analysis of the American data from 1909 to 1949 , revealed that $87.5 \%$ of economic growth within the period was attributed to technological change and $12.5 \%$ to the increased use of capital. The result of this growth model was that financial institutions only exerted a considerably low influence on the rate of investment in physical capital and that changes in investment are considered as having only minor effects on economic growth [1].

Endogenous growth theory on the hand explains longrun growth as one that originates from economic activities that create new technological knowledge.

Endogenous Growth is long-run economic growth at a rate determined by forces that are internal to the economic system and not the result of forces that impinge from outside [32]. Economic growth, as measured by the output per person in the long-run, is dependent on the growth rate of total factor productivity, which in turn is also determined by the rate of technological advancement. The basic difference here is that the neoclassical growth theory of Solow [30] and Swan [31] sees the rate of technological change as exogenous (i.e. something to be determined by a scientific process that is independent of and outside the economic system) which is not the view of Endogenous growth theory.

Endogenous growth theory challenges this neoclassical view and proposes that changes in technology which influence economic growth are rather part of and inside the economic system. It is observed and explained that technological progress takes place through innovations, in 
the form of new products, processes and markets, many of which are the result of economic activities. For example, through the theory of learning firms become more efficient in production with time as a result of accumulated experience. It is also argued that many innovations result from Research \& Development (R\&D), thus policies which may affect $R \& D$ with regard to trade, competition, taxes, intellectual property, etc. which are all part of the economic system can be formulated in a manner to affect the frequency of innovation.

\section{E. An Overview Of The Trend Of Economic Performance Of Ghana}

The growth record of Ghana has seen a random fluctuation. With an impressive high GDP growth in the 1950 s and early 1960s, the Ghana's economic growth as measured by GDP began to experience a slowdown in the mid-1960s. The economy exhibited a somewhat a turbulent growth during the 1960s and only began to stabilize by 1984 . In 1966, 1972, 1975-1976, 1979, 1980-1983 fiscal years, the rate of economic growth was negative. The negative growth periods generally were coincidentally the periods when the country also changed government and sometimes had policy changes [33].

Fosu [33] observed that negative economic growth was recorded for the first time during the time of the first coup d'état, which saw the overthrow of Kwame Nkrumah regime for power to transfer to military regime headed by General Ankrah. The lowest growth of $-14 \%$ was experienced in 1975 , coinciding with the oil-supply shock as well as a policy reversal from a free market operation economy to an inwardlooking protectionist system. However, during those periods of economic fluctuation the country also recorded some positive growth trends, with the highest growth rate reaching 9\% in 1970 and 1978.

The Economic Recovery Program (ERP), under the International Monetary Fund and the World Bank, was instituted beginning in April of 1983, with actual implementation covering 1983-1986. The ERP, a marketoriented program, was intended to halt the downward economic trend and to help the economy pick up [33]. Along the line the Structural Adjustment Program (SAP), which was geared toward correcting a number of structural imbalances also came in.

The economy appeared to have positively responded to the ERP and the SAP program. It recovered from its negative growth rate of about 5\% in 1983 to an impressive positive rate of $8 \%$ in 1984 . This favourable growth continued since that time, with relatively little variance, though there seems to be a slight slowdown in the rate of growth since 1990. The per capita GDP trend is quite similar to economic growth as measured by raw GDP, suggesting that the common denominator which is population growth has been fairly stable.

Per capita GDP generally kept its value of about 500 US dollars until about 1975 when its downward trend began, hitting a record low of 344 dollars in 1983. It picked up again in 1984, maintained after the introduction of ERP in 1983 and continued till it reached nearly 403US Dollars in 1996. The growth trend fluctuated again from 1997 to 2002 fiscal periods but began to pick up from 2003. The per capita GDP however, continued to see an impressive increase till 2011 where the per capita GDP recorded a high of a little over USD1594.

\section{F. Empirical Review Of Credit Supply And Economic Growth}

\section{Domestic Bank Credit Supply and Economic Growth}

While some empirical studies have lent support to the fact that there exists a positive relationship between domestic credit supply and economic growth in various economies others have found a negative relationship between the two variables. Also, the significance of the long-run and short-run relationship between the two variables has been mixed. With regard to the causal relationship between the variables, some empirical results are lending support to the Supply-leading hypothesis advanced by Schumpeter [7]; others are showing results favouring the Demand-following hypothesis.

Nwaru and Okorontah [21] investigated the significance of banks credit in stimulating output (GDP) and the factors that determine financial intermediation within the economy of Nigeria. Findings from their work indicated that the marginal productivity coefficient of bank credit to the domestic economy (proxied by credit to the private sector) is positive but insignificant. They explained that bank's credit did not impact the productive sectors enough for the latter to in turn impact significantly on the Nigerian economy. They also observed that real output measured by GDP causes financial development, and not the other way round and that export were not significant in driving financial development. However, growth in financial sector was highly dependent on foreign capital inflows. They therefore recommended that a strong and comprehensive legal framework that will enhance monitoring of the performance of credit to the private sector and recovery of loans owed to banks be put in place, so that banks will exhibit a strong desire to lend to the private sector of the economy. The direction of causality therefore runs counter to Ogwumike and Salisu [34] who also using Nigerian data examined the short run, long run and the causal relationship between financial development and economic growth in Nigeria from 1975 to 2008. Using the Bound test approach, they found a positive long run relationship between financial development and economic growth in Nigeria. Also, financial intermediation which they measured using credit to private sector, stock market and financial reforms as proxies exerted significant positive impact on economic growth. Further analysis of the short run dynamics revealed that about $40 \%$ of the resulting disequilibrium is captured each period indicating minimal deviations from the equilibrium. In addition, the result of the VAR-Granger causality test lent support to the supply-leading hypothesis. They therefore recommended that appropriate regulatory and macroeconomic policies that will foster the expansion and development of the Nigerian financial institutions should be pursued by the relevant authorities.

Simwaka et al [35] examined the relationship between financial development and economic growth in Malawi using the autoregressive distributed lag (ARDL) approach. Results indicated that there is positive and significant relationship between financial development and economic growth in the long-run. Granger causality tests showed that economic growth drives financial development with no feedback 
effects thus supporting the Demand-following hypothesis. This was the case for two indicators of financial development, namely, private sector credit as a percent of GDP and private sector credit as a ratio of domestic credit. They also found a weak relationship between economic growth and bank deposits as a percent of GDP. According to them the results imply that economic growth is vital for development of the financial sector in Malawi. As a policy recommendation, they indicated that appropriate policies must be put in place to support development of growthenhancing financial sector.

They concluded that for financial development to have a positive effect on economic growth, it is necessary that the expansion of the financial system be accompanied by an increase in the flow of funds towards productive investment activities.

The case of Malawi as indicated by Simwaka et al [35] seems to be opposed by Yakubu and Affoi [1] who analyzed the impact of the commercial banks credit on economic growth of Nigeria from 1992 to 2012. Using ordinary least square (OLS) estimation technique, it was found that the commercial bank credit to the private sector has a significant effect on the growth of the Nigerian economy. They made the following recommendations to the effect of increasing and sustaining commercial bank credit to the private sector:

- Better and stronger credit system should be promoted and sustained;

- There should be strong and comprehensive legal framework that will help monitor the performance of credit to private sector and also deal with recovery of debts owed to banks;

- Banks should accumulate and share information on bad debt;

- $\quad$ Preferred sectors like agriculture and manufacturing should be of preference in terms of granting loans.

Abubakar and Gani [23] also re-examined the long run relationship between financial development indicators and economic growth in Nigeria over the period 1970-2010 in the face of the difficulty in accessing finance despite the implementation of several financial reforms in that country. Interestingly, using the Johansen and Juselius [38] approach to co-integration and Vector Error Correction Modeling (VECM), the findings of their study revealed that in the longrun, liquid liabilities of commercial banks and trade openness exert significant positive influence on economic growth. However, credit to the private sector, interest rate spread, and government expenditure have significant negative influence on the economy of Nigeria. The findings implied that, credit to the private sector is negated by the problems of government borrowing and high interest rate which crowd out investment and growth, they explained. They therefore recommended that financial reforms in Nigeria should focus more on deepening the sector in terms of financial instruments so that private firms would have alternatives to banks' credit which are inefficiently allocated and thus tend to be detrimental to growth. Moreover, government should inculcate the habit of fiscal discipline so as to reduce excessive borrowing from the financial sector and thereby crowding out private investments.

\section{RESEARCH METHODOLOGY}

\section{A. Introduction}

\section{Study Design And Sampling Technique}

The study conducted is exploratory in nature and the sampling technique used is non-probabilistic. Precisely, purposive sampling technique was used in selecting data and its source. The reason for the adoption of purposive sampling method is that, as already indicated the study is exploratory in orientation and it intends to achieve a specific purpose which is to estimate the impact of financial intermediation on the growth of Ghana's economy. Thus, I applied judgment in selecting variables that were particularly informative and targeted at achieving the set objectives of the study.

The approach for this study was purely quantitative. Secondary data relating to financial intermediation and economic growth was relied upon. One main independent variable namely domestic Banks Credit to the Private Sector (BCPS) in Ghana was considered as a proxy to measure financial intermediation. Also, the economic performance or growth (i.e. the dependent variable) of Ghana's economy was measured using Per capita Gross Domestic Product (PGDP).

The economic model adopted for the study was controlled for other factors that in the researcher's opinion were likely to exert a considerable impact on Ghana's economic growth. Factors selected include Interest Rates (INTR) representing the price for acquiring banks credit and the total inflows from the economic natural resources of Ghana termed as Total Natural Resources rent (TNR).

Several approaches have been adopted for similar studies. For instance, King and Levine [5], [6] adopted cross country growth regression; Malede [39] applied panel data techniques and Nwaru and Okorontah [21] also used time series methodology. Demetriades and Andrianova [40] argue that it is cumbersome to come out with any realistic policy implication from cross-country or panel regression. They also indicate that conclusions that may be drawn from time series studies for individual countries may only be applicable to the case country (country-specific) and cannot be generalised. Demetriades and Andrianova [40] further explain that time series methodology has the advantage of allowing the use of appropriate statistical methods such as co-integration to establish whether or not there is an existence of a long run relationship between dependent and independent variables.

This study therefore adopted time series methodology as it used data from Ghana for a specified period of time.

\section{Model Specification And Variable Measurement}

To estimate the extent to which financial intermediation in Ghana's economy influences economic growth, the following econometric model was used:

$$
\text { Economic growth }=f(\text { Financial intermediation })
$$

Thus,

$$
P G D P=f(B C P S)
$$

Adding the control variables that are also expected to exert an appreciable impact on economic growth apart from the financial intermediation variable being studied, the function 
becomes:

$$
P G D P=f(B C P S, I N T R, T N R)
$$

where $P G D P$ is the Per capita Gross Domestic Product used as a proxy for economic growth and BCPS, INTR and TNR represent Banks Credit to the Private Sector, Interest Rates and Total Natural Resources rent respectively.

Transforming expression (3) into a linear form using the logarithm, $L$ of the variables the estimating equation then becomes:

$$
L P G D P_{t}=\beta_{0}+\alpha_{1} L B C P S_{t}+\alpha_{2} L I N T R_{t}+\alpha_{3} L T N R_{t}+\varepsilon_{t}
$$

where $\beta, \alpha$ and $\varepsilon$ are the constant, coefficients of the independent variables and the error term at time, $t$ respectively. The $L$ before each variable denotes a logarithm of that variable. The variables used were transformed into logarithmic form so as to minimize the scale effect.

From theory, an increase in private sector credit if such credit is efficiently applied for innovative activities should lead to an increased economic growth as explained by Schumpeter [7]. Therefore, following from theory and some empirical evidence from other countries such as Nwaru and Okorontah [21] - Nigeria, Ogwumike and Salisu [34] Nigeria and Simwaka et al [35] - Malawi, the study expected a positive relationship between financial intermediation variable (banks credit to the private sector) and economic growth.

Similarly, it was expected that Total Natural Resources rent as a control variable would exhibit a positive relationship with economic growth since an increase in the inflows from natural resource wealth of a country theoretically should generate economic growth and provide governments with an opportunity to support human development [41]. The study finally also expected a negative relationship between interest rates and economic performance as higher lending rates theoretically makes banks credit unattractive to the private sector which means that innovative projects which will generate economic growth eventually do not get financed.

\section{Estimation Technique}

To estimate the parameters in the econometric model stated above using times series data, Auto-Regressive Distributive Lag (ARDL) bounds testing approach to cointegration developed by Pesaran et al [42] was employed. The reason being that estimating the unknown parameters using OLS technique as adopted by Yakubu and Affoi [1] may lead to spurious results and misleading conclusions especially when the variables are non-stationary. It is important to indicate that ARDL has superior advantage over other estimating techniques in that ARDL is still efficient and gives robust results even with small size observations and can also be applied regardless of whether the underlying variables are purely I(0), I(1), or mutually integrated. It therefore does not require pre-testing of stationarity or the order of integration of variables used as required by other approaches to co-integration such as OLS, Johansen, etc. However, although ARDL bounds testing approach to cointegration does not necessarily require unit root test, it is still relevant to test for the order of integration of the variables so as to be certain that the variables are not integrated of the order which is more than $\mathrm{I}(1)$ since the presence of $\mathrm{I}(2)$ variables invalidate the use of the computed $F$-statistic. The reason behind this is that bounds test approach is premised on the assumption that the underlying variables or series are either I(0) or I(1) or mutually integrated.

\subsection{Test For Stationarity (Unit Root Test)}

In order to overcome the possibility of drawing conclusions and inferences that are premised on false results associated with unexpected order of integration of the data series used in this study, unit root test was conducted to ascertain the order of integration of the variables applied in the study. Methods such as the Philip-Perron (PP) test and Augmented Dickey Fuller (ADF) test have widely been used by researchers to test for stationarity properties of time series data. This study employed both the Augmented Dickey Fuller (ADF) test and Philip Perron (PP) test of unit root to determine the order of integration of the variables applied in the model.

The ADF test is of the form:

$$
\Delta q_{t}=\beta_{0}+\alpha_{1} q_{t-1}+\alpha_{2}(t)+\sum \rho i \Delta q t-i+\varepsilon_{t}
$$

where, $\Delta$ is the first difference operator, $q$ is the variable under consideration, $\beta_{0}$ is the constant term, $\alpha_{1}$ is the coefficient being tested, $\alpha_{2}$ is the trend coefficient, $\sum \rho i \Delta q t-i$ is the summation of all past values of the variable under consideration which is being employed to eliminate the effect of autocorrelation with $\rho_{i}$ being the coefficient and $\varepsilon_{t}$ is the error term The study tested the null hypothesis of unit root (non-stationarity) against the alternate hypothesis of stationarity.

If the result of the order of integration yields a mixture of $\mathrm{I}(1)$ and $\mathrm{I}(0)$, or simply a result of I not exceeding one, then co-integration among variables used would be tested using the Auto-Regressive Distributed Lag (ARDL) model. Cointegration here means variable series having a long-run relationship between them.

\subsection{Test For Co-Integration Using ARDL Technique}

As indicated earlier on, ARDL model was applied to establish whether or not there is a long-run relationship (cointegration) as well as short-run relationship between time series variables used for the study due to the above enumerated advantages ARDL has over other co-integration approaches. The ARDL model for testing the existence of cointegration among variables is specified using lags of variables determined by the Schwarz-Bayesian Criterion (SBC). The specification process involves three (3) stages as indicated by Pesaran et.al [42]. The first step involves the application of OLS method on the model equation (6) formulated below:

$$
\begin{array}{r}
\Delta L P G D P_{t}=\beta_{0}+\sum_{i=1}^{k} \alpha_{1 i} \Delta L P G D P_{t-i}+\sum_{i=1}^{k} \alpha_{2 i} \Delta L B C P S_{t-i} \\
+\sum_{i=1}^{k} \alpha_{3 i} \Delta \operatorname{LINTR}_{t-i}+\sum_{i=1}^{k} \alpha_{4 i} \Delta \operatorname{LTNR}_{t-i}
\end{array}
$$

$+\alpha_{5} L P G D P_{t-1}+\alpha_{6} L_{B C P S} S_{t-1}+\alpha_{7}$ LINTR $_{t-1}+\alpha_{8} L T N R_{t-1}+\varepsilon_{t}(3 a)$ 
To establish the existence of co-integration among the variables, the test uses the F-statistic

In the above expression (6), $\Delta$ is the first difference operator, $k$ is the lag length, $\alpha_{5} \ldots . . . \alpha_{8}$ represent the long-run coefficients and $\beta_{0}$ is the drift. The other variables have their usual definition as before. The first half of equation (6) with the coefficients $\alpha_{1 \mathrm{i}} \ldots \alpha_{4 \mathrm{i}}$ represents the short run dynamics of the model, whereas the second half with coefficients $\alpha_{5} \ldots . . . \alpha_{8}$ represents the long run relationship between variables.

The study tested for the null hypothesis of no cointegration against the alternate hypothesis of the existence of co-integration among the variables being studied.

The test hypothesis is given as:

$$
H_{0}: \alpha_{5}=\alpha_{6}=\alpha_{7}=\alpha_{8}=0
$$

$H_{1:} \alpha_{5}, \alpha_{6}, \alpha_{7}$, and $\alpha_{8}$ are all not equal to zero

Thus, to test for co-integration among variables the computed $F$-statistic is compared with two sets of critical values: the upper bound critical values and the lower bound critical values. If the evaluated $F$-statistic falls below the lower bound critical value, the null hypothesis of 'no cointegration' cannot be rejected but if the $F$-statistic exceeds the upper bound critical value, the null hypothesis of 'no cointegration' is rejected implying that the variables under consideration are co-integrated. In other words, there is an existence of long run equilibrium relationship among the variables. However, if the calculated $F$-statistic falls between the upper bound value and the lower bound value the decision is inconclusive and hence to make any conclusive deduction, knowledge of the order of the integration of the variables under study is required [42]. Once the test establishes the existence of co-integration among variables, the next stage is to determine the long-run and the short-run dynamics of the underlying variables applying the ARDL model. The estimation of the long-run dynamics between the variables under consideration was done using equation (7) constructed below:

$$
\begin{gathered}
L P G D P_{t}=\beta_{0}+\sum_{i=1}^{k} \alpha_{5 i} L G D P_{t-i}+\sum_{i=1}^{k} \alpha_{6 i} L B C P S_{t-i}+ \\
\sum_{i=1}^{k} \alpha_{7 i} L I N T R_{t-i}+\sum_{i=1}^{k} \alpha_{8 i} L T N R_{t-i}+\varepsilon_{t}
\end{gathered}
$$

The lag length, $k$ of the variables was selected based on the Schwarz-Bayesian Criterion (SBC).

Also, the short-run dynamics of the variables was estimated using the Error-Correction Model (ECM) constructed as:

$$
\begin{array}{r}
\Delta L P G D P_{t}=\beta_{0}+\sum_{i=1}^{k} \alpha_{1 i} \Delta L P G D P_{t-i}+ \\
\sum_{i=1}^{k} \alpha_{2 i} \Delta L B C P S_{t-i}+\sum_{i=1}^{k} \alpha_{3 i} \Delta L I N T R_{t-i}+ \\
\sum_{i=1}^{k} \alpha_{4 i} \Delta L T N R_{t-i}+\phi E C M_{t-1}+\varepsilon_{t}
\end{array}
$$

where all variables and terms retain their usual meaning as defined above, $E C M_{t-1}$ is the error correction term which helps to determine the stability of the model and how the model adjusts to short-term shocks to the independent variables. Also, the parameter, $\phi$ is the coefficient of the error correction term which measures the speed of adjustment after a shock.

Finally, the Cumulative Sum (CUSUM) and Cumulative
Sum Square (CUSUMSQ) stability tests as suggested by Pesaran and Pesaran [43] were conducted to examine the stability of the model used.

\section{Source Of Data And Definition Of Variables \\ 4.1. Source of Data}

The study used time series data spanning from 1986 to 2011 implying that a total of 26-year observations was used for the estimation. The data was sourced from the World Development Indicator of the World Bank [44]. The size of the data is relatively small hence the researcher's resolve to employ ARDL model as an estimation technique since this technique is efficient even with small sample size.

\section{RESUlts ANALYSIS AND DISCUSSION}

\section{A. Introduction}

This chapter analyses and discusses the results and findings of the study in detail. The discussion of the findings is based on theoretical and empirical evidence.

\section{B. Results Of Unit Root Test}

Though the use of ARDL technique of co-integration does not necessarily require pre-testing of unit root, it was done in order to be certain that none of the variables was of second order of integration, I(2).

The Augmented Dickey-Fuller (ADF) test conducted on the data used for the study indicated that the variables were all of the first order of integration, I(1). This result is confirmed by the Philips-Perron approach to unit root testing.

Thus ideally, Johansen technique of co-integration should have been applied for this study since all the variables were stationary at I(1). However, due to the superior advantage ARDL technique has over other techniques to co-integration, especially for small sample observation, it was still appropriate to adopt bounds testing approach for the study despite all variables being I(1).

The results of the unit root test are reported below in Table 1 and 2 .

TABLE 1A: UNIT ROOT TEST

\begin{tabular}{ccc}
\hline Variables & \multicolumn{2}{c}{ Order of Integration } \\
\hline LPGDP & ADF & PP \\
LBCPS & $\mathrm{I}(1)$ & $\mathrm{I}(1)$ \\
LINTR & $\mathrm{I}(1)$ & $\mathrm{I}(1)$ \\
LTNR & $\mathrm{I}(1)$ & $\mathrm{I}(1)$ \\
\hline
\end{tabular}

TABLE 1BUNIT ROOT TEST

\begin{tabular}{ccccc}
\hline Variables & \multicolumn{2}{c}{ Level } & \multicolumn{2}{c}{ First Difference } \\
\hline & ADF & PP & ADF & PP \\
LPGDP & $0.545620(0)$ & $0.349992(1)$ & $-3.891326^{*}(0)$ & $-3.891326^{*}(0)$ \\
LBCPS & $-1.339494(0)$ & $-1.448922(25)$ & $-6.107412 *(0)$ & $-7.502139 *(13)$ \\
LINTR & $-0.891881(0)$ & $-0.875145(1)$ & $-5.241522 *(0)$ & $-5.241522^{*}(0)$ \\
LTNR & $-0.945669(0)$ & $-0.776282(1)$ & $-5.750390 *(0)$ & $-5.735894 *(1)$ \\
\hline
\end{tabular}

Notes: * represents significance at $1 \%$ significance level. Also, the numbers put in parenthesis, (.) in Table1(b) denote the Lag length selected based on 
Schwartz Information Criterion (SIC) under ADF approach and Bandwidth under PP approach.

\section{Results Of Co-Integration By ARDL Technique}

The ARDL technique used showed that the variables employed for the study are co-integrated. In other words, the ARDL test run established a long-run relationship between the variables. The co-integration results are presented in Table 3 below. The maximum lag length used is one (1) and it is selected based on Schwartz-Bayesian Criterion (SBC).

The results showed that at a lag length of 1 , the computed F-statistic (i.e. 5.7494) exceeds the 95\% upper bound critical value of 5.1809 rejecting the null hypothesis of 'no cointegration' and rather establishing a long-run relationship among the variables.

TABLE 3:RESULTS OF CO-INTEGRATION BY ARDL TECHNIQUE

\begin{tabular}{ccccc}
\hline Regressor & Coefficient & Std. error & T-ratio & Probability \\
\hline LPGDP(-1) & 0.78002 & 0.081492 & 9.5718 & {$[0.000]$} \\
LBCPS & -0.19687 & 0.073914 & -2.6635 & {$[0.015]$} \\
LINTR & -0.024228 & 0.16605 & -0.14591 & {$[0.886]$} \\
LINTR(-1) & -0.46517 & 0.1813 & -2.5657 & {$[0.019]$} \\
LTNR & -0.25396 & 0.15663 & -1.6214 & {$[0.121]$} \\
LTNR(-1) & 0.78814 & 0.18507 & 4.2587 & {$[0.000]$} \\
INPT & 0.99289 & 0.29707 & 3.3423 & {$[0.003]$} \\
\hline
\end{tabular}

R-squared $=0.9579$.

R-bar-squared $=0.9446$.

F-statistic $=5.7494$

95\% Upper Bound $=5.1809$.

\section{Results Of Estimated Long-Run Coefficients Using} $A R D L$

TABLE 4: ESTIMATED LONG-RUN COEFFICIENTS USING ARDL APPROACH

\begin{tabular}{ccccc}
\hline Regressor & Coefficient & Std. error & T-ratio & Probability \\
\hline LBCPS & -0.89497 & 0.44741 & -2.0003 & {$[0.060]$} \\
LINTR & -2.2248 & 0.63468 & -3.5054 & {$[0.002]$} \\
LTNR & 2.4284 & 0.85471 & 2.8412 & {$[0.010]$} \\
INPT & 4.5136 & 0.76026 & 5.9369 & {$[0.000]$} \\
\hline
\end{tabular}

The result of the long-run coefficients of the variables under investigation is reported in Table 3 above.

The result indicates that banks credit to the private sector (LBCPS) used as a proxy to measure financial intermediation is negatively related to the economic growth of Ghana in the long-run, though statistically insignificant at 5\% significance level. The negative long-run relationship between credit to the private sector and Ghana's economic growth is a result that deviates from expectation and also runs counter to some empirical studies such as Ogwumike and Salisu [34] and Simwaka et al [35] using data from Nigeria and Malawi respectively.

However, the result is consistent with Abubakar and Gani [23] who also found a negative relationship between private sector credit and economic growth using data from Nigeria.

The deviation may be accounted for by the following two (2) reasons:

First, according to the proponents of the supply-leading hypothesis of the finance-economic growth nexus (e.g. [7]), the supply of credit to the private sector helps boost economic growth when such credits are efficiently applied for innovative projects or investments. The private sector is often touted as the source of innovative ideas and new inventions which require financing of a sort to bring them to fruition so as to exert the desired positive impact on the entire economy. Thus, it is theoretically anticipated that credit advanced to the private sector would generate economic growth. However, if credit to the private sector is applied by private entrepreneurs and their firms for mere commercial importation of goods from abroad to be sold in the local economy as observed by Nwaru and Okorontah [21], the result of private sector financing could be devastating to the economy. This is usually the case in Ghana as import activities is the main business of most private businessmen. Though private firms may be making good profit, such trade activities are not inventions to drive and catalyze the desired economic growth. Importation financing via private sector credit rather turns out to negatively impact the economy in the long-run since foreign goods are only being promoted in the local economy at the expense of indigenous products.

Financing of import activities of the private sector could kill economic prospect in the long-run because such activities weaken the value of the Ghana Cedi as a local currency against foreign currencies. Import activities also do not promote employment creation in the long-run since private sector credits are not channeled into production.

Nwaru and Okorontah [21] observed that private sector credit could not sufficiently affect Nigerian economy and explained that a chunk of private sector credit get into the hands of importers of foreign goods for sale in the domestic markets and that bank credit rarely get to real inventors whose activities positively and significantly affect economic growth.

The second reason that may account for the negative relationship between private sector credit and economic growth is the fact that cost of bank credit (interest rates) which negatively impact economic growth is too high in Ghana and other developing economies as Kwakye [22] observes.

The high interest rates on banks credit to the private sector negates or counters and in the long-run erodes the positive impact innovative private business financing would have exerted on the economy. This explanation is in line with the reason assigned by Abubakar and Gani [23] for the negative relationship between private sector credit and the growth of the Nigerian economy.

Both Kwakye [22] and Abubakar and Gani [23] noted that the high interest rates in Ghana and Nigeria respectively are the results of the competitive borrowing by government.

The underlying factor that underpins both reasons advanced above is the fact that Ghana's financial system is under-developed. Due to the under-developed nature of financial systems in Ghana, especially the derivatives market, the banking sector seems to lack the requisite capacity to effectively and efficiently manage risk inherent in banking business. This is evidenced by the preference of banks to lend to government at no risk and the high lending interest rates with banks in Ghana to cater for every loss they suffer financially.

Again, due to the under-developed financial system in Ghana banks tend to have low risk-tolerance level and would 
simply not tolerate the high risk associated with financing of new and innovative projects and inventions which have the potential of catapulting economic growth but whose outcomes are not so certain and predictable. Banks would prefer financing import-for-sale trading activities which certainly generates high profit within a short period to enable them to recoup their funds (principal plus interest) in a short while, though such import-for-sale business does not promote economic growth as explained above.

Also, the result of the estimated long-run coefficients of the variables used in the study reveals that there is statistically significant negative long-run relationship between interest rates (cost of borrowing) and Ghana's economic growth. This result meets theoretical expectation and it is also consistent with empirical evidence such as Obamuyi [45] and Abubakar and Gani [23] who both used data from Nigeria.

Theoretically, high interest rates make acquisition of loans by private firms costly and unattractive. Innovative ideas from the private sector which have the potential of driving economic growth may therefore be shelved due to high cost of funds. This in the long-run could cause a shrink in the productive sectors of the economy and reduce economic growth.

Abubakar and Gani [23] observed that high interest rates erode the supposed positive influence that private sector credit should have had on the economy. Soyibo and Olayiwola [46] cited in Obamuyi [45] observed that high lending rate is detrimental to productive investments and hence to economic growth because borrowers with worthwhile projects may be discouraged from seeking loans. They further added that in an environment of high lending interest rates, moral hazard which is detrimental to bank survival and economic growth also sets in as loan seekers only borrow to escape bankruptcy rather than financing innovative projects.

Thus, low and stable interest rates is a requirement for economic growth in that they create economic certainties that encourage investors to borrow and invest in productivityenhancing projects.

Finally, the result also indicates a statistically significant positive long-run relationship between total natural resources rents and Ghana's economic growth with the coefficient showing a commanding influence on economic growth. This result is in line with theoretical reasoning and also it is empirically consistent with the findings of Hamdi and Sbia [47].

Using co-integration and error correction techniques, Hamdi and Sbia [47] found a positive long-run relationship between natural resources rent and the growth of the Algerian economy.

Africa Progress Report [41] explained that an increase in revenue from natural resource wealth of a country theoretically generates economic growth and provides governments with an opportunity to support human development.

From the results of the long-run coefficients estimates, it can be deduced that a unit increase/ (decrease) in the total natural resources rents (LTNR) of Ghana increases/(decreases) the country's economic growth (LPGDP) by 2.43 fold. It is also observed that any gains made in the economy via increase in revenues from natural resources are offset by an increase in lending interest rate. This is because the result indicates that interest rate equally exerts statistically significant long-run impact on the economy of Ghana as natural resource rent does with an impressive coefficient also similar to that of the natural resources rent but in the reverse direction (i.e. -2.22). Hence as $1 \%$ rise in natural resources rent causes $2.43 \%$ rise in economic growth, a $1 \%$ rise in interest rates simultaneously causes economic growth to decline by $2.22 \%$ thereby nullifying the positive impact of natural resources rent on the economy.

This therefore dictates that monitoring and management of interest rate movements as well as general management of various risk exposures by banks should be given the attention and prominence it deserves by policy makers and the handlers of Ghana's economy.

\section{E. Error Correction Representation Of The Selected ARDL Model}

The result of the short-run dynamics of the variables shown by the Error Correction Model is presented below in Table 5.

TABLE 5: ERROR CORRECTION REPRESENTATION OF ARDL (SEE APPENDIX IV)

\begin{tabular}{ccccc}
\hline Regressor & Coefficient & Std. error & T-ratio & Probability \\
\hline$\partial$ LBCPS & -0.19687 & 0.073914 & -2.6635 & {$[0.015]$} \\
OLINTR & -0.024228 & 0.16605 & -0.14591 & {$[0.885]$} \\
$\partial$ LTNR & -0.25396 & 0.15663 & -1.6214 & {$[0.120]$} \\
ECM(-1) & -0.21998 & 0.081492 & -2.6994 & {$[0.013]$} \\
\hline
\end{tabular}

R-Squared $=0.67435$.

R-Bar-Squared $=0.57151$.

F-Statistic $=5.7494$.

The short-run relationship between bank credit to the private sector and economic growth is negative and statistically significant at 5\% significance level. In the shortrun this result is expected because even if private sector credit goes to fund innovative projects, the desired positive impact will not be felt in the short-run. It will take some considerable amount of time for the fruits of innovative investments to trickle down into the economy. The result of the error correction representation of the selected ARDL model reported in Table 5 above also indicates that the Error Correction Term (ECT) is statistically significant at 5\% significance level. More importantly, the ECT carries the appropriate sign which is negative. The coefficient of the error correction term which measures the speed of adjustment to the long run equilibrium after a shock is $22 \%$. This implies that about $22 \%$ of the disequilibria are corrected in the current year. Overall, the regression results suggest that the underlying ARDL model fits the data reasonably well as the R-squared and adjusted R-squared of 0.67435 and 0.57151 respectively of the error correction model appear moderately high. The adjusted R-squared of 0.57151 means that about $57 \%$ of the variations in Ghana's economic growth as measured by Per Capita GDP is explained by changes in the underlying explanatory variables used in the study after adjusting for degrees of freedom. 


\section{F. Parameter Stability Test}

Finally, the study examined the stability of the Error Correction Representation of the ARDL model selected by applying the CUSUM and CUSUMSQ stability tests as suggested by Pesaran and Pesaran [43]. Since the stability test results indicate that neither CUSUM nor the CUSUMSQ plots crosses the critical bounds of $5 \%$ significance level, the null hypothesis that all coefficients in the error correction representation of the selected ARDL models are stable over time is accepted. The results thus agree with the evidence of no significant structural instability and hence it is unlikely that the selected ARDL models suffered from significant problem of misspecification which could lead to spurious results and misleading inference.

TABLE 6: ARDL MODEL OF DiAGNOSTIC TEST

\begin{tabular}{cccc}
\hline Test Statistic & & $\begin{array}{c}\text { LM } \\
\text { Version }\end{array}$ & Probability \\
\hline Serial Correlation & CHSQ(1) & 0.05304 & {$[0.818]$} \\
Functional Form & CHSQ(1) & 0.50004 & {$[0.479]$} \\
Normality & CHSQ(2) & 1.3957 & {$[0.498]$} \\
Heteroscdasticity & CHSQ(1) & $2.00 \mathrm{E}-04$ & {$[0.989]$} \\
\hline
\end{tabular}

The results reported in Table 6 above indicate that the model used passes the various diagnostic tests and thus go to confirm that the model applied does not suffer from any structural defects.

\section{CONCLUSIONS AND RECOMMENDATIONS}

\section{A. Summary Of Findings}

In this paper, the long-run and short-run relationship between domestic bank credit to the private sector (as a measure of financial intermediation) and per capita GDP (measuring economic growth) of Ghana was examined using the ARDL bounds testing approach to co-integration spanning the period 1993-2018.

The test established that there is a stable long run relationship between per capita GDP used as response variable and bank credit to the private sector, lending interest rate and total natural resource rents all as explanatory variables. The existence of a stable long run relationship between the variables is further enhanced by the negative and significant coefficient of the error correction term (ECT).

The study also revealed from the short-run dynamics that about $57 \%$ of the variations in Ghana's economic growth as measured by Per Capita GDP is explained by changes in the underlying explanatory variables used in the study after adjusting for degrees of freedom.

The CUSUM and CUSUM of squares stability test conducted also showed no evidence of any significant structural instability of the long-run coefficient of the output function.

Overall, the empirical evidence obtained indicates that there is a negative long-run relationship between domestic banks credit to the private sector and Ghana's economic growth, though statistically insignificant at 5\% significance level. In the short-run however, the negative relationship between the two variables is statistically significant at the same significance level.

Interestingly, the two other variables used in the study namely, lending interest rates and total natural resource rents both showed a statistically significant long-run relationship with Ghana's economic growth at 5\% significance level coupled with a commanding influence over future changes in economic growth. This is evidenced by their approximately equal but opposite high coefficients. Thus, while interest rates showed a statistically significant negative long-run relationship with the growth of Ghana's economy (with a coefficient of -2.22), total natural resources rents indicated a statistically significant positive long-run relationship with Ghana's economic growth (with a coefficient of +2.43 ).

\section{B. Conclusion}

The estimation results suggest that the main explanatory variable which is private sector credit as well as other variables namely lending interest rates and total natural resource rent used in the model play crucial role in explaining the variations in the long run per capita GDP in Ghana. This empirical evidence means that domestic banks credit to the private sector, interest rates and total natural resource rents are in part jointly responsible for future variations in Per Capita GDP.

It is also striking to infer from the empirical findings that movement of lending interest rates in the Ghanaian economy is pivotal to economic development as its negative impact could outdo the positive impact of other economic variables.

In the researcher's estimation, the study has successfully achieved the purpose for which it was carried out.

\section{Recommendations}

Based on the empirical evidence gathered from this study, the following recommendations are highlighted:

There should be a deliberate policy direction to deepen and intensify the financial system of Ghana to enhance competition among lenders so as to drive down the cost of borrowing in the country. Deepening the financial system in Ghana will promote vibrant derivatives market where most banking risks could be dealt with through the purchase and sale of such financial instruments as futures, forwards, options and swaps.

Also, there should be concerted policy strategy to identify and provide financing for real indigenous inventions and innovative projects by banks with the associated risks borne by the state. This will encourage Ghanaians to put their ingenuities to work so as to promote economic growth. Indigenous inventions and innovative investments have the potential of substituting import-driven activities via the exports of indigenous product. This will generate foreign exchange to shore up the value of the local currency and in the long-run grow the economy of Ghana. Government should also put in place concrete measures to reduce drastically its domestic borrowing from the banks as this drives up lending interest rates and tends to 'crowd out' private sector investments which potentially could lead to economic growth. Finally, proceeds from oil, gold and other natural resources of the state should judiciously and efficiently be applied as total natural resources rents have been found to have statistically significant positive impact on the economy of Ghana with an impressive coefficient. 
Further research could be conducted using SMEs as the base for receiving financial support from the banks to see how their contribution would be in contributing to economic growth and national development

\section{REFERENCES}

[1] Yakubu, Z. and Affoi, A.Y. (2014). An Analysis of Commercial Banks' Credit on Economic Growth in Nigeria,Current Research Journal of Economic Theory, 6 (2), pp. 11-15.

[2] Agbada A. O. (2010). Banking System Credit as an Instrument of Economic Growth in Nigeria, Bullion: Publication of Central Bank of Nigeria. 34, 30-35.

[3] Nwanyanwu, O.J., (2010). An Analysis of Bank Credit on the Nigeria Economic Growth (1992-2008). Jos J. Econ.,[60].4: 43-58.

[4] Adeniyi, O. M (2006) "Bank credit and Economic Development in Nigeria" A case study of Deposit money Banks, Jos Journal Of Economics, University Of Jos.

[5] King, R. \& Levine, R (1993a) "Finance and Growth: Schumpeter Might Be Right," Quarterly Journal of Economics, 108(3), pp.717-737.

[6] King, R. \& Levine, R (1993b) "Finance, Entrepreneurship, and Growth: Theory and Evidence." Journal of Monetary Economics, 32, pp.513-542.

[7] Schumpeter, J.A., 1934. The Theory of Economic Development Cambridge. Harvard University Press, Mass.

[8] McKinnon, R. (1973). Money and Capital in Economic Development. Washington DC: The Brookings Institution.

[9] Estrada G., Park D., and Ramayandi A. (2010). "Financial Development and Economic Growth in Developing Asia". ADB Economics Working Paper Series No. 233.

[10] Johannes, A.T.; Njong, A.M.; Cletus, N. (2011) Financial development and economic growth in Cameroon, 1970-2005. J. Econ. Int. Financ., 3, 367-375.

[11] Goldsmith, R. W., (1969), Financial Structure and Development. New Haven: Yale University Press.

[12] Gurley, J. \& Shaw, E. (1967) "Financial structure and Economic Development" Economic Development and Cultural change, Vol 15, No. 3.

[13] Robinson, J. 1952. The Generalisation of the General Theory, In The Rate of Interest and Other Essays, McMillan, London.

[14] Beck, Thorsten, Asli Demirgüç-Kunt, and Vojislav Maksimovic. (2003). "Financial and Legal Institutions and Firm Size" World Bank mimeo.

[15] Levine, R (2002). "Bank-Based or market-Based financial system: which is better?" Journal of financial intermediation N0. 11.

[16] Boyreau-Debray, G. (2003). "Financial Intermediation and Growth: Chinese Style," The World Bank, Policy Research Working Paper Series 3027.

[17] Oluitan, R. O. (2012). Bank Credit and Economic Growth: Evidence from Nigeria. International Business and Management, 5 ( 2), : 102110.

[18] Bigsten, A., Collier, P., Dercon, S., Fafchamps, M., Gauthier, B., Gunning, J., Soderbom, M., Oduro, A., Oostendorp, R., Pattillo, C., Teal, F., \& Zeufack A. (2000). CSAE Working Paper Series No. 200024, Center for the Study of African Economies, University of Oxford.

[19] Loening, J., Rijkers, B., and Soderbom, M. (2008). Non-farm Microenterprise Performance and the Investment Climate: Evidence from Rural Ethiopia. World Bank, Policy Research Working Paper No. 4577.

[20] Soderbom, M. (2000). Investment in African Manufacturing: A Microeconomic Analysis. Center for the Study of African Economies, Manor Road, Oxford.

[21] Nwaru, N. M and Okorontah, C. F. (2014). Banks' Credit as an Instrument of Economic Growth in Nigeria. International Journal of Business \& Law Research, 2(2), 2533.

[22] J. K. Kwakye (2012) Financial Intermediation and the cost if Credit in Ghana. No. 36 IEA Monograph.

[23] Abubakar, A. and Gani, I. M. (2013). Impact of Banking Sector Development on Economic Growth: Another Look at the Evidence from Nigeria. Journal of Business Management \& Social Sciences Research (JBM\&SSR), 2 (4): 47-59.

[24] Spencer, H.M., 1977. Contemporary Macroeconomics. 3rd Edn., Worth Publishers, New York.

[25] Dewett, K.K (2005). Modern Economic Journal of Development Economics. Theory. New Delhi:shyam Lev Charitable trust.

[26] Todaro, M.P. and S.C. Smith, 2006. Economic Development. 9th Edn., Pearson Education Ltd., England.
[27] Ochejele, J.J., 2007. Economic Analysis. Ichejum Press, Jos

[28] Scholtens, B. and Wensveen, D. V. (2003), The Theory of Financial Intermediation: An Essay on What it does (not) Explain, European Money and Finance Forum (SUERF), Vienna.

[29] Franklin Allen, Anthony M. Santomero (1997). The theory of Financial intermediation. Journal of Banking \& Finance Vol. 21, issue 11-12, 1461-1485.

[30] Robert M. Solow (1956) The Quarterly Journal of Economics, Vol. 70, No. 1. pp. 65-94.

[31] Swan, T. W. (1956) Economic growth and capital accumulation. Economic Record, 32 (2), 334-361

[32] Romer, Paul M., "New Goods, Old Theory and the Welfare Costs of Trade Restrictions," Journal of Development Economics, forthcoming February 1994, 43: 1.

[33] Fosu, A.K. (2001). "The Global Setting and African Economic Growth," Journal of African Economies, Vol. 10, No. 3, pp. 282-310.

[34] Ogwumike, F. O. and Salisu, A. A. (2012) Financial development and economic growth in Nigeria. Journal of Monetary and Economic Integration 12(2), 91-119.

[35] Simwaka, K., Ligoya, P., Kabango, G. and Chikonda, M. (2012) Money supply and inflation in Malawi: An econometric investigation. Journal of Economics and International Finance, 4 (2), 36-48.

[36] IMF, 2001. Theories of Economic Growth-Neo-Classical. Retrieved form:

http://tutor2u.net/economics/content/topics/econgrowth/theory_neocl assical.htm. (Accessed on: November 20th, 2013).

[37] Nnanna, O.J., A. Englama and F.O. Odoko, (2004). Financial Market in Nigeria. Kas Arts Service, Abuja.

[38] Johansen, S. and Juselius, K. (1990) Maximum likelihood estimation and inference on cointegration with appucations to the demand for money. Oxford Bulletin of Economics and Statis tics 52(2), 169-210.

[39] Malede, M. (2014) Determinants of Commercial Banks Lending: Evidence from Ethiopian Commercial Banks. European Journal of Business and Management, 6(20), 109-117.

[40] Demetriades, P. and Andrianova, S. (2004) Finance and growth: What we know and what we need to know. Financial Development and Economic Growth, 38-65.

[41] Africa Progress Report (2013) Equity in Extractives: Stewarding Africa's Natural Resources for All. AP Panel- Geneva: Africa Progress Panel.

[42] Pasaran, S.H., Shine, Y and Smith, R. J. (2001) Bound Testing Approach to the analysis of level of relationship. Journal of Applied Statistics, 16, 289-326.

[43] Pasaran, M. H and Pasaran, B. (1997) Working with Microfit 4.0Interactive Econometric Analysis, Oxford University Press, Oxford.

[44] WDI (2013) International Bank for Reconstruction and Development / The World Bank 1818 H Street NW, Washington DC 20433.

[45] Obamuyi, T.M. (2009) An investigation of the relationship between interest rates and economic growth in Nigeria, 1970-2006. Journal of Economics and International Finance 1(4) 093-098.

[46] Soyibo, A. and Olayiwola, K. (2000) Interest Rate Policy and the Promotion of Savings, Investment, and Resource Mobilization in Nigeria. Development Policy Centre.

[47] Hamdi, H. and Sbia, R. (2013) Dynamic relationship between oil revenues, government spending and economic growth in an oildependent economy. Economic Modelling 35, 118-125. 